\title{
Research and Exploration on the Cultivation of Innovative and Enterprising Japanese Talents
}

\author{
Junyue Qi \\ Department of Foreign Japanese \\ Dalian Neusoft University of Information \\ Dalian, China 116023
}

\begin{abstract}
The aim of foreign language education in Colleges and universities in different periods and under different backgrounds should be consistent with the country's foreign policy and economic construction. With the development of the national economy and the "public entrepreneurship and innovation" up to the national strategic level, the Japanese Major in college and university should take the talent cultivation face to who of innovative entrepreneurial awareness and ability to the new talent training objectives. Stimulate and cultivate college students' interest and enthusiasm about innovation and creation to promote the innovation and development of the whole society. To achieve the goal, the university should explore new training mode and teaching methods, so as to make the innovation and entrepreneurship education of Japanese major become more and more perfect.
\end{abstract}

Keywords-innovation and entrepreneurship; Japanese talents; training

\section{INTRODUCTION}

In 2014, the Chinese Prime Minister Li Keqiang at the summer Davos forum was first proposed "public business, and highly innovative" concept. Subsequently, the Forum in Davos, Switzerland the opening ceremony, the prime minister also delivered a special speech by Li Keqiang, the first "Mass entrepreneurial, highly innovative "As the Chinese economy, "The new engine ". General Secretary Xi Jinping, China's president, after listening to "Thirteen-Five" period noted the observations and recommendations of the Economic and Social Development, to stimulate innovation and passion to mobilize the whole society, breakout shows keep up. We should accelerate the formation of economic system and development mode guided by innovation. In 2015 the government works report. Premier Li Keqiang also promoted "mass entrepreneurship and innovation" to the strategic height of the new engine of national economic development. This indicates that China has entered a "new era of innovation and entrepreneurship".

It should state the reason "public business, and highly innovative "raised to the height of the new engine of national economic development strategy. Because of "public business, and highly innovative " meaning is not only caused by " innovation " to achieve social improvement of employment, But also through " innovation ", led to cultivate and create new impetus to economic and social development, stimulate the creative potential of the whole society.

The first platform of the university as a young student should be in touch with the community, with particular emphasis on innovation and enterprise education for college students. All professions and disciplines should integrate the innovation and entrepreneurship education with professional education through adjusting and innovating the existing talents training mode, to arouse and cultivate students' innovation and entrepreneurship interest and enthusiasm. And ultimately, we can cultivate innovative and compound talents for the society, better contribute to the quality of college students' employment, entrepreneurship, and then promote the innovation and development of society as a whole.

\section{THE NeCESSITY OF CUlTIVATING INNOVATIVE ENTREPRENEURIAL TALENT IN JAPANESE}

The purpose of foreign language education in different periods and backgrounds should be consistent with the national foreign policy and economic development goals. With the development of national economy and the transfer of " public business, and highly innovative " raised to a national strategic level, foreign language majors in Colleges and universities should design and train foreign language professionals with innovative and entrepreneurial awareness and ability into new talents training objectives. To achieve this, the talents training patterns of English majors in colleges should change the past.

\section{A. Current Situation of Talent Cultivation in Japanese}

In recent years, with rapid development of Japanese funded enterprise software and services outsourcing industry. The industry needs more widely and increasingly specialized technical requirements, the Japanese has its unique needs and characteristics of the industry. At the same time, we also see that due to the rapid development of mobile Internet and the changing international economic environment, software and services outsourcing industry is facing unprecedented changes. The combination of Japanese talents training and software and service outsourcing industry promotes the employment rate of Japanese professionals. At the same time, the development of industry also makes some contradictions between the needs of Japanese talents and the supply of 
Japanese talents: On one hand, their counterparts in the Japanese language school specializing in low employment rate, many Japanese graduates cannot find a suitable job. The other hand, many enterprises of Japanese graduates can't find jobs. Therefore, the traditional Japanese teaching compared with the market demand, there are already lagging behind.

Therefore, colleges should be based on the demand for the Japanese talents of enterprises, follow the law of market economy, oriented by the demand for talent, fit in with the needs of the society, cultivate innovative, comprehensive and Applied Japanese talents with innovative consciousness and mastery of the thinking and skills of mobile Internet.

\section{B. The Necessity of Cultivating Innovative Entrepreneurial Talent in Japanese}

The integration of innovation and entrepreneurship education in Japanese teaching is not only reflected in enhancing students' competitive advantage in employment, improving employment rate, and promoting high quality employment, in the external environment of rapid economic development in other areas also reflects the need for innovation and enterprise education.

1) In accordance with their aptitude, expanding students' career choices after graduation: With the reform of education system, a significant expansion in colleges and universities, China's higher education from elite education to mass education, which brought impact to the schools allocation of resources? In the process of popularization of higher education, the most direct impact is the low quality of students, which leads to relatively weak humanistic quality and cultural accomplishment of students. Part of university students majoring in Japanese not interested. This has not only directly affect the employment rate of graduates in Japanese counterpart, that some students in the choice of graduation also be affected. Therefore, requires teachers for all students, in accordance with their aptitude, within the acceptable range of students' ability to maximize expand students' knowledge, exercise the students' various abilities. Teaching by cultivating the students' awareness of entrepreneurship, to provide more opportunities for college students' employment in the new market economy environment.

2) Conforming to Japanese teaching requirements: As a language subject, the development of Japanese majors requires that the students of Japanese majors need not only have better ability of language application, but also require students of Japanese majors to have many personal abilities and qualities, so that these can adapt to the development of the new era.

Join innovation and enterprise education in Japanese teaching is also very necessary. Innovation and Entrepreneurship Education should be covered in the Japanese majors teaching contents, and is run through the various stages of teaching. The main purpose of Japanese teaching is to enable students not only to write, but also to speak, speak, and dare to speak. This requires the University
Japanese teachers to attach importance to the basic knowledge and the practical ability of spoken language, not only to teach the basic knowledge of Japanese according to the needs in the classroom, but also to carry out the planning guidance for the career development. The teaching of College Japanese is generally focused on the one or two grade in the critical period of the formation of world outlook, outlook on life and values. Therefore, in order to achieve this goal, students of Japanese language learning at the same time, can subtly to entrepreneurship education.

\section{To Carry out the "Innovation and Pioneering Japanese Talents "Facing Problems}

1) Professional Courses subject rarely involves knowledge of entrepreneurship education: At present, most of the training targets of Japanese majors are to train research type or applied Japanese talents, and language courses and professional courses occupy the main position in their curriculum design. Lack of systematic innovation and entrepreneurship education, entrepreneurship education in specialized courses involved aspects of the content is too one-sided, still most of their time and energy into professional courses construction. On Practical Teaching in the curriculum design. On the whole, it also ignores the cultivation of students' creative ability and entrepreneurial practice ability, focusing on the cultivation of students' understanding and mastery of language culture and related professional knowledge.

2) The lack of entrepreneurial education teachers:The teachers with sufficient theoretical knowledge and rich practical experience are the guarantee of the innovation and entrepreneurship education. However, the problem of the construction of the teaching staff is also one of the major problems to be solved in the innovation and entrepreneurship education.At present, the introduction of Japanese professional teachers in colleges and universities mainly to education and scientific standards, most professional teachers with no influence of General Education of innovation and entrepreneurship,Widespread lack of knowledge structure of innovation and entrepreneurship, does not have the interdisciplinary field of knowledge. This led to a general lack of innovation and entrepreneurship coaching skills of teachers.

Additionally, most teachers directly engaged in the teaching job after graduating from college, lack of social and entrepreneurial activity, lack of understanding of company or company's work processes, lack of practical experience. After entering the university, most teachers have been busy upgrading the qualifications and promotion of professional titles. Coupled with the heavy workload of teachers teaching and scientific research, innovation and entrepreneurship often lack systematisms and scientificness management. Therefore, innovation and entrepreneurship is also a new thing for them.

3) The lack of diversity of innovation and entrepreneurship education: Colleges and Universities in order to build a business platform for the students,according 
to the needs of students' development, we should provide corresponding locations and policies and financial support,And Establishment of practice base of innovation and entrepreneurship.In recent years, under the influence of national policy and economic development, various kinds of entrepreneurial competitions have been carried out in various places to encourage college students to participate in various forms of entrepreneurial competition.

But owing to lack of students' consciousness of innovatio $\mathrm{n}$ and entrepreneurship,practical ability is relatively weak, managing, directing and monitoring are not in place, Students are accustomed to completing tasks and jobs under teachers' baton, once independent, you feel at a loss, so students and teachers are still confused about innovation and entrepreneurship. This situation is particularly prominent in the humanities and Social Sciences, and the entrepreneurial platform eventually flows into the form. And at present, many entrepreneurial platforms and entrepreneurial competitions are mostly in the service of computers, electronic commerce, software services and other disciplines. The platform of the humanities is relatively small, especially in the language discipline, and many times are not available.

\section{EXPLORATION OF INNOVATION AND PIONEERING JAPANESE TALENTS}

Education as the main way to cultivate talents to improve students' comprehensive ability and literacy has a positive effect. The Japanese majors in colleges and universities should pay increased attention to and strengthen management, emphasis on students' Subject Status, bold breakthrough talent training pattern in the past, effective Cultivation of innovation talents of Japanese into professional training objectives and training programmes, thus fundamentally improve the students' creative and entrepreneurial abilities.

\section{A. To Establish a Dedicated Full-time Teaching Staff}

At present, a lot of innovation and entrepreneurship teachers in colleges and universities enrich enough, the lack of full-time teachers, entrepreneurship courses by professional instructors or faculty adjunct. This leads to innovation and enterprise education really is, hinder the full implementation of innovation and enterprise education

The Japanese majors in colleges and universities to strengthen the construction of innovation and entrepreneurship teachers, priority should be to strengthen the capacity of existing teachers' quality training. Hire industry experts to lecture training and enrich teachers' knowledge innovation and entrepreneurship. Encourage teachers to participate in hands-on learning, improve the practice ability, the establishment of a Japanese language ability is strong, solid expertise, entrepreneurial literacy, Interdisciplinary Professional teachers. Secondly, the establishment of Entrepreneurship Education Department, strengthen the integration of entrepreneurship courses and specialized courses, to work from the students' Entrepreneurship Education into the teaching profession. In addition, colleges and universities can employ some entrepreneurs with entrepreneurial experience as part-time teachers to participate in innovative and entrepreneurial practice teaching, and integrate the high quality teaching resources of society and enterprises, this not only makes Japanese teachers professionalization, but also promotes students' innovation and entrepreneurship activities and practice application.

In order to promote the internationalization training model of Chinese entrepreneurial talents, I think it is necessary to cultivate an interdisciplinary and international entrepreneurial Japanese teaching team, to introduce highly educated graduates from Japan and to further enrich the Japanese teachers' team.

\section{B. To Reset the Course System and Strengthen the Integration of Vocational Education and Enterprise Education}

At present, the courses of innovation and entrepreneurship education in Colleges and universities are generally universal courses, which fail to integrate Japanese majors with professional education. The Japanese majors should regard cultivating students' innovative consciousness and practical ability as the goal; perfect the curriculum system of innovation and entrepreneurship. We try to add the course of innovation and Entrepreneurship of Japanese specialty to the original professional course system in the form of professional elective course and professional compulsory course, and gradually melt into the course of professional teaching. The combination of Enterprise Education in Japanese teaching and effective and the original curriculum can increase the proportion of innovation and entrepreneurship courses, and strengthen students' creative consciousness. In the popularization of innovation and enterprise education atmosphere and improve the quality of entrepreneurship and entrepreneurial practice ability of students.

In the course of professional basic courses, we should emphasize and highlight the cultivation of students' thinking ability, add innovative thinking courses and carry out debate competitions and speech competitions widely in some student activities, which will play a great role in promoting the development of students' creative thinking. In addition, through the teaching and system guidance, in the high grade curriculum, the students' needs are added to the special innovation and entrepreneurial learning plate for the students to be selected for the interest of the students, so as to lay a solid foundation for the students to innovate and start a business.

At the same time, the design of the curriculum system should be closely related to the training of students' innovative and entrepreneurial ability, mobile Internet research and development skills, service outsourcing professional skills, foreign language professional ability and software engineering. Introducing the corresponding teaching tools and adopting the teaching mode combining theory with practice to provide the students with the opportunity to innovate the practice of entrepreneurship and Practice for the enterprise, and to establish a complete career 
and innovation and entrepreneurship training course and service system.

\section{Rich Entrepreneurship Training Base}

At present, most of the existing college students' Entrepreneurship centers or entrepreneurial bases are dominated by engineering or business schools, while the practical teaching bases for the training of Japanese professional entrepreneurial talents are very scarce. Part led to the university's Entrepreneurship Education is limited to groups, but not in the majority. In order to improve this situation, Japanese majors can set up a practical teaching base for themselves. The teachers lead the students to guide the students to work together and carry out a series of campus cultural activities, such as the Japanese animation culture exhibition, the Japanese food culture festival and so on. Entrepreneurship contest will be held on such diverse topics of practical projects, cultivating students' quality and ability of the essential core of entrepreneurship

At the same time, Japanese majors can use school enterprise cooperation to build practical training bases, communicate with foreign enterprises and enterprises with trade contacts with Japan, provide students with opportunities for part-time job, social investigation and practice, and help students improve their Japanese practical ability. It is also possible to try to establish communication and contact with the enterprises of Nihon University or Japan, and to make students feel the corporate spirit and human characteristics of Japan on the ground through professional training or short-term study.

Through the outside school practice base, it can effectively make up for the lack of actual work experience of college students, and understand the great differences between school and workplace, and between study and work; It can also make the students understand and consolidate the Japanese professional knowledge, and feel the culture and environment of Japanese enterprises, and enhance the practical ability of understanding, analyzing and solving problems. Thereby to the community for the future, ready to be fully operational and ready, lay the groundwork for official work ahead. At the same time, it can also provide the choice for the employment of the enterprises, which can help the scholars to further understand the actual situation of the current social development for Japanese professionals and lay the foundation for the students to take the job in advance.

\section{INNOVATIVE ENTREPRENEURIAL PROSPECTS FOR THE JAPANESE TALENTS CULTIVATION}

With the development of the national economy and the emphasis on innovation and entrepreneurship, the traditional forms of innovation and entrepreneurship education are changing gradually. We should change the traditional education concept, change the training idea, form the allround system of the training of creative and entrepreneurial talents, optimize the course setting, strengthen the construction of the teachers, build up the platform of innovation and entrepreneurship education, provide the students with the space of study and study to the maximum, and stimulate the creative thinking of the students. Dimension, improve students' entrepreneurial skills and practical ability, and enable students to become high-quality professionals with both professional knowledge and innovative vision.

\section{CONCLUSION}

Countries are " public business, and highly innovative " ra ised to the height of the newengine of national economic dev elopment strategy. Therefore, Japanese majors in universities should design Japanese talents with innovative and entrepreneurial awareness and ability into new talents training objectives. In order to achieve this goal, we must solve the problem that teaching involves little knowledge about entrepreneurship education, and the construction of teaching staff. Japanese majors in Colleges and universities should pay more attention to and strengthen management, break through the former mode of training talents, and cultivate innovative and entrepreneurial Japanese talents into professional training objectives and training programs, and thus fundamentally improve the students' innovative and entrepreneurial ability. Finally, it can realize the cultivation of innovative and compound talents for the society, and better promote the high quality employment and Entrepreneurship of college students, and then promote the innovation and development of the whole society.

\section{REFERENCES}

[1] Zhang Siyao. Deep Thinking in Foreign Language Talents entrepreneurial capacity -building in the northeast[J].Journal of Dongbei University of Finance and Economics,2016(3): 91 - 97.

[2] Jing Li.Research and Exploration of entrepreneurial talent training model in colleges and universities - In Japanese, for example[J]. Journal of Hubei Institute of Technology, 2015(1): 159 - 168.

[3] Cong Huiyuan.Study on the integration of vocational education and enterprise education in Higher Vocational Colleges - In Japanese, for example[J] Journal of Hubei Corresponpence University, 2016(5) : $13-14$.

[4] Zhang Shiqing,Wang Xuying. In the economic development of Wenzhou on training mode of innovative talents in Japanese [J] techno-culture, 2013(8): 130-133.

[5] Xiang Jie. Japanese major innovative imbark personnel training mode of innovative research [J].modernization of education, 2016(4):1719.

[6] Piao Jing. With scientific development view of Japanese Teaching Model of cultivating pioneering talents[J]. impart knowledge and educate [cultivate] people, 2011(6):102-103. 